\section{The Art of Survival: Policy Choices for Nepal}

\section{Dev Raj Dahal}

\section{Abstract}

The tendency to change foreign policy tilt with every change in government has posed difficulty for Nepal to maintain internal cohesion and external adaptation. Now the nation is suffering from ceaseless spasms of political instability because many of its statebearing institutions are broken and new are not yet invented to glue the nation's diverse society and get viable traction to balance neighborhood geopolitics and become relevant to international community. In this context, Nepal now needs a regime that fosters centripetal tendencies of domestic forces for a cohesive and coherent foreign and security policy strategy to survive and prosper in a world dominated by protagonist giants and devise material, institutional and symbolic bases of the nation to scramble safe future.

Keywords: geopolitics, national interests, adaptation, sovereignty, nation-state and human rights.

\section{Introduction}

The defining feature of international system is anarchic. It is anarchic because there is no super sovereign authority over states to maintain global order and enforce rules. Therefore, national security is the highest end. States compete with other states to maximize their power for national security. Anarchical situation ensures that security will be scarce and "an increase in one state's security will decrease the other's security" (Jervis, 2000:185). This situation keeps the states in a security dilemma. The structural and normative edifices of world order seem "unable to provide minimum human security for the peoples of the world" (Falk,
1995:29). The distribution of power and authority among various states, non-state actors and international institutions has carried on an anarchical international system in which risk of violence, widespread poverty, inequality, unemployment, ecological damage and abuse of human rights increasingly threaten human survival. This view holds that "the keys to war and peace lie more in the structure of international system than in the nature of individual states" (Mearshiemer, 1999:109). Even the internal defense of nationalism is caused by external security competition. The gap between de-territorialized technological, communication, economic and ecological spaces and territorialized political states governing national security and defining international regimes has posed a complexity in defining national security perimeter.

Major transformations in four interrelated areas of international politics have enlarged the scope of national security. First, the concept of sovereign nation-state defined by Westphalian monopoly of power has gone into new transmutation. The demise of cold war has increased intra-national conflict as minorities increasingly challenge the writ of state to share sovereignty. Public international laws and humanitarian laws restrict the state's excessive use of force against its own citizens. Second, decline of highly connected neo-liberal global economic order has moved geopolitical discussion away from G-7 Washington Consensus. The birth of G-20 has pluralized the centers of power. Third, drift of center of political gravity of international affairs from the Atlantic to the Asia-Pacific region has strengthened the concept of geo-economic regionalism and multi-literalism. And fourth, transnational ecological, social, gender and peace movements of civil society have increased. They reclaim popular sovereignty, security, justice and identity. This requires reassessing the sources of insecurity and their coping strategies.

In this changed context, how can national security interest of Nepal be defined and linked with the architecture of human security? National interest is defined by overall environment, policies and actions beneficial to all citizens. It stands above the interest of subsidiary caste, class, ethnic, territorial and economic interest groups. National interest establishes the inseparability of policy and national security, the importance of territorial integrity and 
freedom of the state. Such interest can be placed into an order of priority: survival, vital, major and peripheral interests. The statecentric security is essential but not sufficient to grasp the social dynamics of modernity generated by media of communication that cuts across geopolitical boundaries of nation-state. In an interconnected world national interests have to be pursued not only by shielding national institutions but by increasing their competitiveness. Therefore, national security issues have to be analyzed by National Security Council in terms of linkages of individual, sub-national, nation-state, regional and global levels and their centripetal and centrifugal tendencies of societal forces. The indivisibility of national security also means that all the forces of nation, including security agencies, civil servants, political parties, NGOs, civil society and citizens must abide by certain shared rules-a commitment to the sovereignty, territorial integrity and life-chances and define strategic concept to deal with the sources of insecurity through effective conflict prevention, conflict management and crisis resolution mechanism to defuse and dissipate threat before they escalate.

Normally, national security measures "the absence of threats to acquired values" and "absence of fear that such values will be attacked" (Wolfers, 1981:150). Similarly, national interest can also be judged along time dimensions. This makes certain national interest variable, less permanent factor as vital interest at one time becomes survival at another time, major interest at another time and peripheral still another time. ${ }^{1}$ There is a correlation between national interest and national security. Security of Nepal means

${ }^{1}$ Survival interests are non-negotiable. They are related to the continuous and interrupted existence of the state, national security, territorial integrity and national independence. The ability of the nation to foil attack or to defeat it lies on its survival fitness and its capacity to withstand internal subversion and external pressures. Vital interests are those interests that are essential for the nation-building and maintenance of a national identity, political stability, economic development and peace by increasing the competitive strength of the nation. It is grounded in the core values of the nation. Major interests are associated with the management of vital resources-human, natural, social and financial and strengthening the state's raison d' etat where cooperative interests can be harnessed for mutual benefit. Peripheral interests are relatively less important for the short run but they have the potential to effect long-term development of the nation, for example, protection of non-resident Nepalese, workers and refugees of Nepalese origin. security of its people, space, values, resources and identity and realization of the objective and subjective rights of state and citizens so that they live in reasonable harmony and peaceful coexistence with other peoples and states. Nepal cannot be separated from the Nepalese people, land, tradition, issues and symbols though territorial organization of modern social life has been stretched to regional and global communication and transnational movements of both positive and negative factors have made common cause with local actors.

In post-conflict phase, there are a number of concerns to be answered. Is Nepal facing a sense of claustrophobia or exercising freedom of choice due to its vital geo-strategic position in the heartland of Asia? What kind of national interest do the Nepalese people prize high in their ranking and put pressure on the leadership to defend and promote? What is the specific interest part of government's security policy? How are particular interests of various political parties, market institutions, civil society and individuals generalized to make them national interest and tied to national security, stability, progress and peace? This paper narrates Nepal's geo-strategic advantage, historical legacy, independent identity, balancing strategies and a conclusion as they all pertain to national security of Nepal.

\section{Geo-Strategic Advantage}

Nepal's geographical location inside the immediate orbit of two advanced technological super-states - China in the north and India in the east, south and west, each with over one billion population, leading infrastructure, software technology industries, high growth markets and highest engagement of multilateral institutions, potentially makes it a transit corridor for increased Sino-Indian trade, commerce and diplomatic competitiveness. Nepal looks small before the huge landmass, power potential and the historical image of these neighbors - China as a dragon and India an elephant. But by the global comparison, it is average- sized.

Similarly, the resiliency of its statehood has far surpassed both the neighbors demonstrating its nature as a defensive hedgehog with adequate freedom to maneuver. Its location in the geopolitical underbelly of China, Tibet and India's heartland states of Uttar 
Pradesh, Bihar and West Bengal constitutes its strategic geography vital to their security, stability, progress and peace. Nepal's geophysical location has defined its exposure, circulation, transaction pattern and communication more to the south than the north. Until recently, "the high caste Hindu elite in Nepal has identified with India's Sanskritic culture and geo-strategic world of South Asia" (Rose and Andersen, 1986: 248) and shaped foreign policy behavior accordingly. An increasingly open, secular and democratic Nepal in the future is more likely to be swayed by the ongoing geo-strategic competition between the regional and global powers for their influence and deconstruct this Sanskritic worldview.

Nepal treasures 83,000 MW hydro energy potential and remains a paradise for Himalayan adventures. Demand for energy in modernizing India is enormous. The cap of Mt. Everest and Nepal's ecological and cultural diversity are major sources of tourist attraction. Nepal's management of climate change and utilization of hydropower bear significant implications for the future of 500million people of Gangetic belt. The existence of holy places: Pashupati Nath and Janaki Temples and Lumbini, the birth place of Gautam Buddha, has until recently enthused a sense of cultural rootedness and belonging. But, ahistorical and so called secular leaders of Nepal are less interested in soft power of national ideas and culture and more in hard power-resources, economy, trade, investment and technology. Breaking of a vicious trap between poverty and insecurity is essential to instill a sense of feeling of appreciation of ancestor's contribution. As globalization continues to unglue its historically evolved centripetal forces, trigger the anti-systemic social movement and denationalize them on the basis of self-chosen linkages, the nation will certainly become a site of internal conflicts of greedy elites nourished by geo-strategic contest of the external drivers of conflict if the historical tradeoff persists between democracy and nationalism. There is a strong correlation between the two as both make political leaders accountable to citizens. The internal security dilemma has already stalled the peace process in Nepal.

Existence of over hundred insurgent groups in Tarai, Nepal's southern flatland and simmering crisis in Tibet involve the high stake of neighbors as they pose an external security dilemma. India's engagement with various dissident groups in Tarai and steady shift of the electoral geography to South is designed to contain the effect of UCPN (Maoist)'s rise in Nepal and protect its "inner ring of buffer" through a cordon of friendly forces. Shayam Sharan, the special envoy of Indian Prime Minister, on May 20, 2008 stressed the implementation of accord between the Nepal government and the Madhesi parties for a single federal autonomous Madhesh evoking the wrath of Tharus, Muslims and non-Madhesi hill population living in Tarai for centuries and weakening the center's centripetal role in the periphery. His next visit to Nepal on August 4, 2010 to facilitate discussion among Nepali leaders for building national consensus on constitution drafting and peace process has, however, generated distrust as he is reported to have told Madhesi leaders to go for anti-Maoist coalition in Nepal.

With the disappearance of common cultural glue of Hinduism that tied Hill and Tarai population following the declaration of secular Nepal, the decision-making power of hill, historically defined as political heartland of the country, will likely to corrode in the future. The opening of ancient communal, ethnic and racial cracks by various political parties to expand their political constituencies is weakening the Nepalese state internally as the number of state bearing institutions are diminishing fast. Unless Nepalese leaders define what is essential for the national security and increase economic competitiveness it will be to be swayed by the pressure of regional and global geopolitical imperatives as survival-oriented regime in Kathmandu leaves little scope for constitutional and political stability and creative policy initiatives.

The Indian leadership misjudged the magnitude of the proximity of dynamic China and its reaction in the exploitation of Nepal's internal weakness. But, India would not like to push UCPN (Maoist) to China, the geo-strategic competitor of India and the counter balancer of South Asian politics. Still, containment of China through acquired power will continue to provide conceptual yardstick for the perception of spreading influence of China in the South Asian subcontinent. Similarly, Beijing will not favor Nepal to become a part of anti-China prejudice expressed through 
forward policy in the crest of Himalayas hectoring ethnic selfdetermination and human rights. These policies have instilled the Chinese mistrust of the Nepalese political leadership driven by partisan lust than civilized domestic consensus and increased their geopolitical assertiveness.

The Chinese fears the Indian domination on Nepali agenda on security and geo-economic priorities through multi-leverage on social, political and economic actors. Similarly, India is sensitive over Nepalese leaders' frequent utterances to import petroleum products from China, the Chinese extension of its railway link from Beijing, Khasa to Kathmandu and the likelihood of its political support to UCPN (Maoist) as the later has shown strong interest in revising the peace accord of 1950 with India and Integrated Mahakali Treaty, regulate open border and stop the supply of Nepalese Gurkhas to India and the UK, an imperial legacy of extending Anglo-Indian security perimeter into the heartland of Asian geopolitics. Kodari highway that links Nepal with Tibet through road is functional and Rasuwa will be operational soon. Nepal's interest in other two roads along Koshi River in the east and Lo Manthang in the west fits with the Chinese interest in expanding trade and commerce and improving peopleto-people relations. China's focus on the modernization of its western parts is expected to transform the geopolitics of inner Asia and facilitate the operation of historical Silk Road where the US wants its leadership.

Chinese leader Ai Peng pointed Nepalese human right NGOs and Western governments for supporting Tibetan refugees' protest in the Chinese Embassy in Nepal while Chinese scholar Wang Hongwei fears that India "wants to turn Nepal into a second Bhutan or Sikkim." Despite the nation's "one China policy," Nepal's overdependent on foreign aid does not make it immune from the Indian and the Western pressure to be lenient on human rights concerns of Tibetans fighting for their religious and cultural autonomy. To placate the Chinese concerns the Nepalese government blocked the mountaineers to climb to Mt. Everest, expelled British journalists covering the news and decided to deploy armed police force in the border but allowed the peaceful protest of Tibetans. Then Defense
Minister Ram B. Thapa and his team quietly reached Tibet to discuss with Chinese authorities about cooperation.

On December 1, 2008 the Chinese Foreign Minister, Yang Jiechi, expressed "China's commitment to extend possible assistance to Nepal in protecting its sovereignty, independence and territorial integrity." By throwing the new Comprehensive Peace and Friendship Treaty proposal in 2009 the Chinese government has put UCPN (Maoist) government in a policy trap. In its Article (1) the draft of the treaty states that two sides will cooperate in the prevention and suppression of terrorism, separatism and extremism and illegal border crossing. India wanted to see first the provisions of the treaty before it signs Extradition Treaty with Nepal. Critics argue that by moving close to China the UCPN (Maoist) can neither get itself out nor change the policies that put it in that trap in the first place. Obviously, China wants its enhanced role in Nepal legitimized. The projection of India as a factor of instability and the undue beneficiary of Nepal's resources, mainly hydropower, apparently make Nepal's tilt with China all the more desirable (Ghimire, 2009).

India has also expressed its interest to provide income-generating training to Maoists in cantonment, expand railway network and offer smooth flow of petroleum products to Nepal. On September 14 Prime Minister Bhattarai said, "Nepal wants to be a vibrant bridge between the South Asian region and China, rather than traditional buffer state" against China. Chinese Ambassador to Nepal Yang Houlan told the Nepalese media on October 16, 2011 "We have authentic information that our oldest and nearest friend Nepal is turning into a playground for anti-China activities. Some international and domestic forces are coordinating their activities, against China." Sensing Nepal's tilted foreign policy the US Ambassador to Nepal Scott H. DeLisi speaking to Kathmandu Post journalists on December 12, 2011 said, "You have two large neighbors, India and China and they have been an important part of the foreign policy. The world is bigger than India and China too. And your foreign policy has to be bigger than India and China too.” 


\section{The Historical Legacy}

Nepal was founded in $1769 \mathrm{AD}$ as a modern state by King P.N. Shaha from the nucleus of Gorkha, a tiny Himalayan kingdom. Describing Nepal "a yam between two boulders" he suggested his successors to follow a policy of active defense, economic mercantilism and cultural nationalism. This act was performed at a time when British-India was expanding its empire in Asia and China was confined with the security of Middle Kingdom and the maintenance of its tributary relationship with the neighbors. As Nepal missed the balancing act it was forced to make concessions after being defeated by China in the late $18^{\text {th }}$ century and then by British East India Company in late nineteenth century. Following the signing of Treaty at Sugauli with the latter in 1816 the British Empire consigned Nepal into a position of buffer state precariously dependent on the south for formal socializing agencies, strategic commodities and essential goods. But, as a result of Nepal's military support to British India during Sepoy mutiny of 1857 and facility to recruit its Gurkhas in British army Nepal was able to regain Western part of Nepal and latter signed a peace accord with British in 1923 that recognized Nepal's fully sovereign status. The recruitment of 5,000 Nepalese in the British and 42,000 in the Indian armies still mirrors the legacy of British imperial days. Nepal now accumulates $\$ 1.5$ billion annual remittances from the Nepalese workers from various parts of the world including India and the Islamic world than the armies bring from India and the UK. Every year 400,000 Nepalese enter into labor market, 300,000 of them leave the country due to lack of job opportunities at home. It is fulfilling the goal of geo-economics--to provide the best possible employment for the largest proportion of population (Luttwak, 1999:182) which is essential for the promotion of vital economic and social interest.

The political change of 1950 brought 104 years old Rana oligarchy crashing down and provided a new orientation in foreign policyspecial relationship with India defined by Treaties of Peace and Friendship, Extradition and Trade. In the fifties this special relationship glued by national treatment of each other's citizens, common security, resource utilization and exclusion of third country from taking any project in Tarai, the southern flatlands, melted down with Sino-Indian détente in the 1950s and the subsequent emergence of China as a strong power after collision with India in 1962. This special relationship was further neutralized by King Mahendra in the 1960s through a policy of diversification in aid, trade and foreign relations with the US, the UK, China, Germany, France, the Soviet Union, Japan, Pakistan, Gulf region etc. aiming to escape from regional geopolitical constraints and enhance its freedom of maneuver in international system. Nepal felt that special relationship with India, a euphemism for limiting its freedom, has weakened the concept of national sovereignty coded in pubic international laws and, therefore, sought to minimize the vulnerability to a single power. Historically, "national freedom came to be regarded as a prerequisite as well as a collective manifestation of individual freedom" (Morgenthau, 1946:61).

Assertive extra-regional players provided Nepal a leverage and even choice to cope with the security challenges posed by protagonist neighbors and reduce its excessive dependence on them. With this new menu of choice Nepal rejected the traditionally-ascribed buffer status, ordered the Indian military mission to leave Nepal in 1969, adopted neutralism between SinoIndian conflict and cooperation, formulated equidistance policy during cold war between the regional and global powers, adopted non-aligned posture in its international behavior and tried to project its independent image though Arms Assistance Agreement of 1965 between Nepal and India sought to limit defense cooperation with the Anglo-Saxon bloc. In the future Nepal is likely to promote economic diplomacy to export labor and attract foreign direct investment in tourism, hydropower, industries, social sector development and regional and global economic integration which will erode its introvert policy of isolation, self-distancing, buffer and special relationship. Nepal's stability and progress rests on how it manages the vital interest of neighbors and extra-regional powers and becomes highly relevant to international community in a number of areas including the management of climate change of the Himalayan region. 


\section{2 | Dev Raj Dahal}

\section{Independent Identity}

Nepal's ability to carefully craft balancing act improved its international image and credibility considerably. It became the most accepted country for conference diplomacy and multinational peace keeping operations in the UN. As a result, Kathmandu hosts many offices with regional in scope International Center for Integrated Mountain Development, South Asian Association for Regional Cooperation, UN Disarmament Office for Asia, UNICEF-Regional Office for South Asia and also became a member of non-aligned movement, the UN, the World Trade Organization and Bay of Bengal Initiative for Multi-Sectoral Technical and Economic Cooperation. It was twice elected as a non-permanent member of UN Security Council in the 1960s and 1970s.

To promote mutual interest it banded together with landlocked, least developed and small states in the international fora. Rejecting this buffer status, King Birendra, in the 1970s and 1980s, articulated the nation as a gateway between South Asia and Central Asia. India's assertion of its position following its policy tilt to the Soviet Union in the seventies, active role in the emergence of Bangladesh, annexation of Sikkim, a tiny Himalayan state close to Nepal and nuclear test inspired Nepal to innovate a new policy initiative to be declared as a "zone of peace." During cold-war the United States and major powers maintained close relations with Nepal as a bulwark against the Soviet Union and China while the latter too tried to reduce Nepal's dependence on them through development aid considering that an independent Nepal will have its own sovereign aspirations and will not be manipulated by external powers.

Nepal had also utilized its strategic position to squeeze concessions from the communist and democratic countries to augment its independent position through mixed economy, linguistic, educational and cultural Nepalization and active foreign policy. To project its independent identity, Nepalese leaders followed a policy of Nepalization internally and tried to be different from the neighbors on a number of issues, such as recognition to the right of existence of Israel, opposition to the Soviet invasion of

Afghanistan, peaceful settlement of Gulf crisis, non-interference in Cambodia and adherence to disarmament. Its nonalignment is an alignment with landlocked, least developed and small states in the international forums, a preference for reflecting its strong interest in policy autonomy through the diversification of dependence. But, the fate of 120,000 Bhutanese refuges of Nepalese origin stranded in various camps in eastern Nepal remains unresolved as international community began to settle part of this number to various countries. Irresolution of this refugee problem, border disputes, trade imbalance, cross-border terrorism and controversial decision of the Nepalese government to print machine readable passport in India continue to strain bi-lateral ties. The UK's minister for International Development Alan Duncan in his maiden visit to Nepal on May 26 expressed commitment to support Nepal's development and peace and dubbed "India as obstacle to peace process." India and China both want stability for different reasons - the former wants dependable policy confirming Indian vital interests while the latter inspires Nepal to pursue independent policies based on national interest. Recently, Chinese concern in Nepal grew owing to political instability in Nepal as China considers Nepal an important trading route connecting China with South Asia and has offered multi-sectoral cooperation.

\section{Balancing Strategies}

The country's survival fitness is attributed to its historically evolved balancing tact and the ability to become closer to both neighbors than they are with each other. But, the historical concept of politics defined by the centrality of state has now shifted to market forces, party politics, free trade and financial linkages in 1990s and now to a wide range of audiences, such as class, market, territory, ethnicity, nationalities, NGOs, civil society etc as their free transaction is governed only by their own non-territorial logic (Luttwak, 1999:180). The Nepalese media and intellectuals are socializing the citizens into these new fault line conflicts rather than laying common ground for the resolution of multi-layered conflicts. All the political parties in Nepal are affiliated with like- 
minded political parties across the nation and the politics of democracy, development and peace is decided by how the incumbent parties balance their partisan interest with the state's raison d'etat, worldviews, identity and status (Dahal, 2008:56). Without a sound institutional mechanism for conflict-resolution, the cross-national links of societal forces will continue to contest the geopolitical boundaries of Nepali state and reshape the forces of national constellation. Implementation of partisan approach in foreign policy executing agencies has already undermined the interest of state to represent national interest, national security and overall geopolitical balance.

Nepal's balancing act between India and China has always been precarious akin to a game of national self-assertion versus regional accommodation. The objective of this balancing is both "to minimize the restrictions imposed on Nepal's freedom of action and to contribute to that country's internal and external security" (Rose and Dial, 1969: 89). The balancing act would have been a viable strategy had Nepal achieved self-sufficiency on essential goods. India's imposition in late 1989 of trade blockade on landlocked Nepal in reprisal for its import of arms from China caused a shortage of fuel, salt, cooking oil, gas and other basic commodities, a slump in Nepal's tourist industry and vulnerability to the political movement of 1990 .

Restoration of new elites to power and subsequent signing of Nepal-India Joint Communique by former Prime Minister K. P. Bhattarai and V. P. Singh in June, 1990 in New Delhi dethroned all the previous balancing acts by promising "common rivers, common security, common people, common currency, etc." and deepening Nepal's geo-strategic dependence on India. The subsequent policies to privatize Chinese made industries to reduce Chinese influence, cut of agriculture subsidies and international market integration have, however, generated livelihood crisis. Cut in subsidies and privatization of health, education and communication have provided sufficient root causes for the intensification of UCPN (Maoist)'s People's War, crisis of governance and a lack of any clear direction in foreign policy. Reduction of trade and development gaps of Nepal with the neighbors requires production revolution and reindustrialization of the nation so that economic process can support social and system integration.

The political change of 2006 marked the decline of monarchy in independent foreign policy as the Indian mediated 12-point agreement between ruling parliamentary parties and rebel CPN (Maoist) fostered anti-monarchy agitation and successfully articulated the regime change for democracy, human rights and peace. The UK and the USA also coordinated their policy with India in Nepal and encouraged India to engage in resolving the Maoist and latter Madhesi problems. In the process, then King Gyanendra's policy to project Nepal as a transit state between Asia's two growing economic power houses remained moribund although its prospects has not totally diminished. Sino-Indian trade has trespassed over US $\$ 60$ billion mark while Nepal suffers huge trade deficit with both the neighbors. Like with India, Nepal- China talk focused on the establishment of special economic zones, dry ports in border areas, promotion of tourism and reduction of trade deficit.

In February 2009 the Chinese government presented Nepal a draft of a proposal of Comprehensive Peace and Friendship Treaty, sought guarantee for "one China policy" and pledged to protect Nepal's "sovereignty and territorial integrity." Similarly, Chinese Foreign Policy Spokesperson Jiyang Yu, during a press briefing in Beijing on May 4, urged Nepalese political parties to seek consensus based on national interest which is also interest of regional peace and stability. This statement came in the wake of Indian Prime Minister Man Mohan Singh's total support to Nepalese government led by Madhav Kumar Nepal against UCPN (Maoist)'s nation-wide agitation. Nepalese preferred the presence of United Nations Mission in Nepal (UNMIN) with the hope that the outcome of peace accord would eliminate the cause of structural injustice embedded in regional geopolitics and provide peaceful evolution of Nepal. The UNMIN's role has been achieved in conducting Constituent Assembly election but the integration of Maoist combatants into civilian life remains partially resolved. It has yet to work for confidence building among the conflicting parties as the incumbent regime feels it closer to Maoists. Domestic crisis produced chronic instability in its foreign policy. 


\section{6 | Dev Raj Dahal}

Nepal terribly lost its bid to become a non-permanent member of the UN Security Council third time in 2006 due to fragile image of the state and erosion of its international acceptability. Similarly, it also lost in the election of $66^{\text {th }}$ presidency of UN General Assembly in 2011. These demonstrate that the country has received sympathy from the world community because of its image as one of the poorest and conflict-prone fragile states of the world but lost dignity as a sovereign nation capable of steering an independent and balancing domestic and foreign policy.

The advent of UCPN (Maoist) as a single largest party with its strong preference for equi-proximity as opposed to Panchayati policy of equidistance between the neighbors and global powers has brought Nepal into global focus. At a time when post-2006 regime deconstructed the nation's historic identity of a unitary state, monarchy, Hindu ideology and canceled the national unification day it must find new glue to hold the nation and nationalities together in socialization and civic identity. The growing assertiveness of ethnicity, class, religion and territoriality in the future is likely to weaken its foreign policy coherence if a strong nationalist center is not consolidated to stem the prolonged instability in its economic heartland-Tarai and regional identity is transformed into national identity. Ethnic self-determination paraded by Nepalese parties has evoked ancient hatred in a vicious way thereby undermining the base of social cohesion. The cooperation of the Madhesi People's Rights Forum (MPRF) is a must to defend the cultural identity of Tarai and its existence within the framework of nation-state. It is also a lynchpin to solution of the problems of over hundred armed non-state actors operating independent of a weak and insecure Nepali state. Autonomy at home and sovereign interests abroad are key ingredients for pursuing policy goals and avoiding the trappings of universal ideology. The purpose of Nepalese diplomats abroad is to foster national interests, not defend abstract principles. China has suggested Nepal to reach consensus to resolve peace process and constitution based on national interest.

\section{Conclusion}

Due to the globalization of national societal forces the boundary between domestic and foreign policy is becoming fluid and extrasystemic source of conflict has unsettling consequences for national security. The globalization of modern politics through media and Multi National Corporations, deregulation of economic forces and centrifugal pressure of non-state actors, human rights and civil society groups will certain to put enormous strain on its domestic capabilities for the resolution of conflict at the centerperiphery relations and balance the power of yet to be defined federal states. Despite strong ideological congruity with India and the West following the declaration of federal democratic republic of Nepal, Nepalese leadership finds no option other than to act as a balancer of regional and global interests in the nation's geopolitics. The complexity of conflict in Nepal has inhibited flexibility but its geopolitics has become very difficult to project independent identity, increase its competitiveness and become an independent actor in international politics. Nepali rulers' historically evolved sanskritik spiritual, material and psychological worldview is likely to undergo a new political acculturation as it opens to international influence and the government becomes more unstable and survivaloriented.

A sound national security policy requires an updating of crucial political developments, performing an act of balancing encapsulated in the ancient sensitive yam theory of the nation, improving in civil-military relations, putting self-sufficient state capable of fostering human security. It now needs a regime that fosters centripetal tendencies of domestic forces for a cohesive and coherent foreign and security policy strategy to survive and prosper in a world dominated by protagonist giants and devise material, institutional and symbolic bases of the nation. The success of foreign policy, like appropriate strategy, largely depends on the institutional ability of its execution. 


\section{8 | Dev Raj Dahal}

\section{References}

Dahal, Dev Raj. (2008). "Nepal's Peace Process: The Role of External Actors," Swiss Peace Policy,No. 1.

Dahal, Dev Raj. (2001). "Geopolitics of Nepal: Survival Strategy of a Small State," ed. Anand Aditya, The Political Economy of Small States, Kathmandu: Nepal Foundation for Advanced Studies.

Falk, Richard. (1995). "The Challenge of Politics: Overcoming Realist Myopia, Implementing Rooted Utopianism," eds. Allan Race and Roger Williamson, True to this Earth, Oxford: One World.

Ghimire, Yubaraj. (2009). "Unraveling Nepal," Indian Express, April 10.

Jervis, Robert. (2000). "Offense, Defense, and the Security Dilemma," eds. Robert J. Art and Robert Jervis, International Politics: Enduring Concepts and Contemporary Issues, New York: Longman.

Khatri, Sridhar. (2001). "Nepal in the International System: The Limits of Power of a Small State," Anand Aditya, The Political Economy of Small States, Kathmandu: Nepal Foundation for Advanced Studies.

Khatri, Sridhar. (2008). Assessing and Reformulating SAARC Road Map. Kathmandu: South Asia Center for Policy Studies.

Luttwak, Edward N. (1999). "From Geopolitics to Geo-economics: Logic of Conflict, Grammar of Commerce," The New Shape of World Politics, New York: Foreign Affairs.

Mearsheimer, John J. (1999). "Back to the Future: Instability in Europe After the Cold War,"The New Shape of World Politics, New York: Foreign Affairs.

Morgenthau, Hans J. (1946). Scientific Man Vs Power Politics, Chicago: The University of Chicago Press.

Rose, Leo E. and Roger Dial. (1969). "Can a Ministate Find True Happiness in a World Dominated by Protagonist Powers?:

The Nepal Case, " The Annals, Vol. 386, No. 1, November 1969.

Rose, Leo E. and Walter K. Andersen. (1986). "South Asian Security Problems," eds. Robert A. Scalapino, Seizaburo Sato and Jusuf Wanandi, Internal and External Security Issues in Asia, Berkeley: Institute of East Asian Studies, University of California.

Wolfers, Arnold. (1981). Discord and Collaboration: Essays on International Politics, Baltimore: The John Hopkins University. 